\title{
Bioaccumulation of heavy metals in organs of fresh water fish Cyprinus carpio (Common carp)
}

\author{
*R. Vinodhini; M. Narayanan \\ Aquatic Biodiversity Research Center, Department of Advanced Zoology and Biotechnology, St.Xavier's College, \\ Palayamkottai, Tamilnadu, India \\ Received 8 October 2007; $\quad$ revised 24 November 2007; accepted 12 December 2007; $\quad$ available online 10 March 2008
}

\begin{abstract}
The objective of the present study is to determine the bioaccumulation of heavy metals in various organs of the fresh water fish exposed to heavy metal contaminated water system. The experimental fish was exposed to $\mathrm{Cr}, \mathrm{Ni}, \mathrm{Cd}$ and $\mathrm{Pb}$ at sublethal concentrations for periods of 32 days. The elements $\mathrm{Cd}, \mathrm{Pb}, \mathrm{Ni}$ and $\mathrm{Cr}$ were assayed using Shimadzu AA 6200 atomic absorption spectrophotometry and the results were given as $\mu \mathrm{g} / \mathrm{g}$ dry wt. The accumulation of heavy metal gradually increases in liver during the heavy metal exposure period. All the results were statistically significant at $\mathrm{p}<0.001$. The order of heavy metal accumulation in the gills and liver was $\mathrm{Cd}>\mathrm{Pb}>\mathrm{Ni}>$ $\mathrm{Cr}$ and $\mathrm{Pb}>\mathrm{Cd}>\mathrm{Ni}>\mathrm{Cr}$. Similarly, in case of kidney and flesh tissues, the order was $\mathrm{Pb}>\mathrm{Cd}>\mathrm{Cr}>\mathrm{Ni}$ and $\mathrm{Pb}>\mathrm{Cr}$ $>\mathrm{Cd}>\mathrm{Ni}$. In all heavy metals, the bioaccumulation of lead and cadmium proportion was significantly increased in the tissues of Cyprinus carpio (Common carp).
\end{abstract}

Key words: Toxicity, pollutants, exposure period, gills, liver, kidney, flesh

\section{INTRODUCTION}

The contamination of fresh waters with a wide range of pollutants has become a matter of concern over the last few decades (Vutukuru, 2005; Dirilgen, 2001; Voegborlo et al., 1999; Canli et al., 1998). The natural aquatic systems may extensively be contaminated with heavy metals released form domestic, industrial and other man-made activities (Velez and Montoro, 1998; Conacher, et al., 1993). Heavy metal contamination may have devastating effects on the ecological balance of the recipient environment and a diversity of aquatic organisms (Farombi, et al., 2007; Vosyliene and Jankaite, 2006; Ashraj, 2005). Among animal species, fishes are the inhabitants that cannot escape from the detrimental effects of these pollutants (Olaifa et al., 2004; Clarkson, 1998; Dickman and Leung, 1998). Fish are widely used to evaluate the health of aquatic ecosystems because pollutants build up in the food chain and are responsible for adverse effects and death in the aquatic systems (Farkas et al., 2002; Yousuf and El-Shahawi, 1999). The studies carried out on various fishes have shown that heavy metals may alter the physiological activities and biochemical parameters both in tissues and in blood (Basa and Rani, 2003; Canli, 1995; Tort and Torres, 1988). The toxic effects of $\triangle$ *Corresponding Author Email: swethasivani@yahoo.co.in Tel.: +91 4465420 284; Fax:+91 4622561765 heavy metals have been reviewed, including bioaccumulation (Waqar 2006; Adami et al., 2002; Rasmussen and Anderson, 2000; Rani, 2000; Aucoin et al., 1999). The organisms developed a protective defense against the deleterious effects of essential and inessential heavy metals and other xenobiotics that produce degenerative changes like oxidative stress in the body (Abou EL-Naga et al., 2005; Filipovic and Raspor, 2003). Cichlidae species are the most popular and highly economic fish. In the present research, Cyprinus carpio (Common carp) was selected due to its adoption in polluted aquatic environment. The purpose of this research is to quantify the accumulation of heavy metals in various organs in Cyprinus carpio (Common carp).

\section{MATERIALS AND METHODS}

The freshwater Cyprinus carpio (Common carp) (10$13 \mathrm{~cm}$ length and $35.70 \pm 0.60 \mathrm{~g}$ ) was collected from ponds of southern districts of Tamilnadu, India, and was acclimated to laboratory conditions for a week. The $12 \mathrm{~h}$ photo period was maintained throughout the experimental work. Twenty to twenty-five individuals were used for the experiments. The fish was fed with standard powdered feed and were starved for $24 \mathrm{~h}$ prior to the experimentation. Analytical graded cadmium 
chloride, lead nitrate, potassium chromate and nickel sulphate supplied by BDH (in India) was used as the metal toxicant in this experiments. Fish were divided into five groups, with the first group serving as control and other groups as experimental groups. The experimental groups were administered with a sublethal concentration of $5 \mathrm{ppm}$ of combined metal solution $\left(1 / 10^{\text {th }}\right.$ of $\left.\mathrm{LC}_{50} / 48 \mathrm{~h}\right)$ daily for $1,8,16$ and 32 days. Fish from each group were dissected to separate organs (flesh, gills, liver and kidney) according to FAO methods (Dybem, 1983). The separated organs were put in petri dishes to dry at $120^{\circ} \mathrm{C}$ until reaching a constant weight. The separated organs were placed into digestion flasks and ultrapure concentrated nitric acid and hydrogen peroxide $(1: 1 \mathrm{v} / \mathrm{v})$ (SD fine chemicals) was added. The digestion flasks were then heated to $130^{\circ} \mathrm{C}$ until all the materials were dissolved. Digest was diluted with double distilled water appropriately. The elements $\mathrm{Cd}, \mathrm{Pb}, \mathrm{Ni}$ and $\mathrm{Cr}$ were assayed using Shimadzu AA 6200 atomic absorption spectrophotometer and the results were given as $\mu \mathrm{g} /$ g dry wt. For cadmium and lead a palladiummagnesium nitrate matrix modifier was employed. The detailed analytical procedures for metal determinations were given in the literature (Ritterhoff and Zauke, 1997). Data obtained from the experiments were analyzed and the results were expressed as mean \pm S.D. The results were evaluated using Student's ttest. Values of $\mathrm{p}<0.001$ were considered statistically significant.

\section{RESULTS AND DISCUSSION}

The heavy metals such as chromium (Cr), nickel $(\mathrm{Ni})$, cadmium $(\mathrm{Cd})$ and lead $(\mathrm{Pb})$ were analyzed in different organs like gills, liver, kidney and flesh of the control fish surviving in natural water system. The accumulation of heavy metals in fish species were analyzed at the end of the experimental period and compared with the experimental fish, which were exposed to the selected heavy metals (Table 1). The gill is an important site for the entry of heavy metals that provokes lesions and gill damage (Bols et al., 2001; Lock and Overbeeke, 1981). The range of $\mathrm{Cr}$ was $2.25 \pm 0.05-3.566 \pm 0.015$, Ni was $3.17 \pm 0.075-$ $3.938 \pm 0.035$, Cd was 6.23 $\pm 0.041-6.938 \pm 0.025$ and $\mathrm{Pb}$ was $4.28 \pm 0.025-4.996 \pm 0.0255 \mu \mathrm{g} / \mathrm{g}$ dry wt, respectively during initial to 32 days of exposure. The results indicate that lead and cadmium accumulation was relatively higher than other metals in gills (Fig. 1 ). The liver accumulates relatively higher amounts of heavy metals. The range of Cr was $2.663 \pm 0.031-$ $4.273 \pm 0.015$, Ni was $3.750 \pm 0.026-4.80 \pm 0.025$, Cd was $4.816 \pm 0.015-5.643 \pm 0.012$ and $\mathrm{Pb}$ was $7.336 \pm$ $0.032-8.743 \pm 0.031 \mu \mathrm{g} / \mathrm{g}$ dry wt, respectively. The results indicate that the heavy metal accumulation gradually increases during the exposure period (Fig. 2). The higher accumulation in liver may alter the levels of various biochemical parameters in liver. This may also cause severe liver damage (Ferguson, 1989; Mayers and Hendricks, 1984). Kidney is the gateway for heavy metal detoxification in body. In kidney tissue, considerable amounts of heavy metals were accumulated. The range of $\mathrm{Cr}$ was $2.773 \pm 0.031-3.233$ \pm 0.031 , Ni was $1.873 \pm 0.025-2.426 \pm 0.025$, Cd was $4.310 \pm 0.026-5.320 \pm 0.026$ and $\mathrm{Pb}$ was $6.333 \pm-6.943$ $\pm 0.015 \mu \mathrm{g} / \mathrm{g}$ dry wt, respectively. These results indicate that lead and cadmium strongly accumulated rather than chromium and nickel in kidney (Fig. 3). Flesh is one of the ultimate parts for heavy metal accumulation. The range of Cr was $1.543 \pm 0.021-2.143 \pm 0.015$, Ni was $0.146 \pm 0.015-1.613 \pm 0.031$, Cd was $1.110 \pm 0.017$ $-1.653 \pm 0.021$ and $\mathrm{Pb}$ was $2.056 \pm 0.025-2.730 \pm 0.010$ $\mu \mathrm{g} / \mathrm{g}$ dry wt, respectively. The heavy metals were uniformly spread over the body muscles. Hence, the observed values were relatively lower than the other potential organs. The presence of higher amounts of heavy metals in any parts of the body will definitely induce changes in biochemical metabolisms and other induced stresses (Fig. 4). Studies on the accumulation of heavy metals in various organs of the fresh water fish exposed to sublethal concentrations were very much important.

Table 1: Heavy metal analysis in the different organs of control fish ( $\mu$ g/g.d.wt)

\begin{tabular}{lllll}
\hline Heavy metals & Gills & Liver & Kidney & Flesh \\
\hline $\mathrm{Cr}$ & $0.790 \pm 0.026$ & $0.863 \pm 0.015$ & $0.943 \pm 0.021$ & $1.083 \pm 0.021$ \\
$\mathrm{Ni}$ & $1.043 \pm 0.021$ & $0.973 \pm 0.021$ & $0.790 \pm 0.010$ & $0.633 \pm 0.015$ \\
$\mathrm{Cd}$ & $1.883 \pm 0.015$ & $1.693 \pm 0.015$ & $1.166 \pm 0.015$ & $0.646 \pm 0.025$ \\
$\mathrm{~Pb}$ & $1.400 \pm 0.020$ & $2.000 \pm 0.017$ & $1.900 \pm 0.020$ & $1.460 \pm 0.036$ \\
\hline
\end{tabular}

Note: The values were statistically significant at $\mathrm{p}<0.001$. 


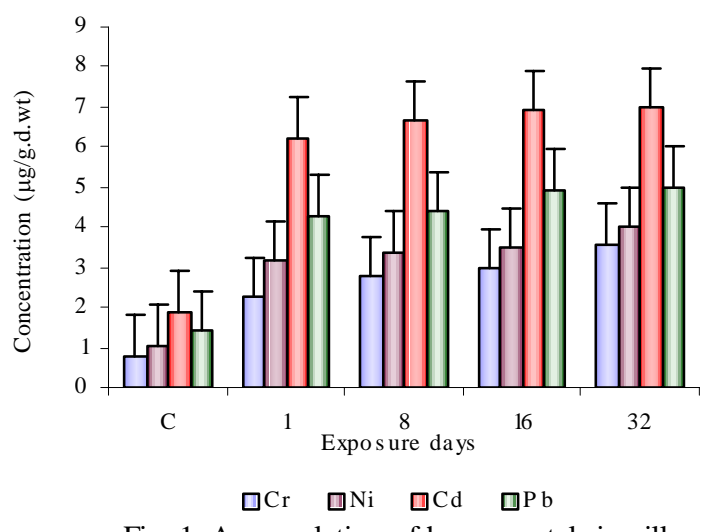

Fig. 1: Accumulation of heavy metals in gills

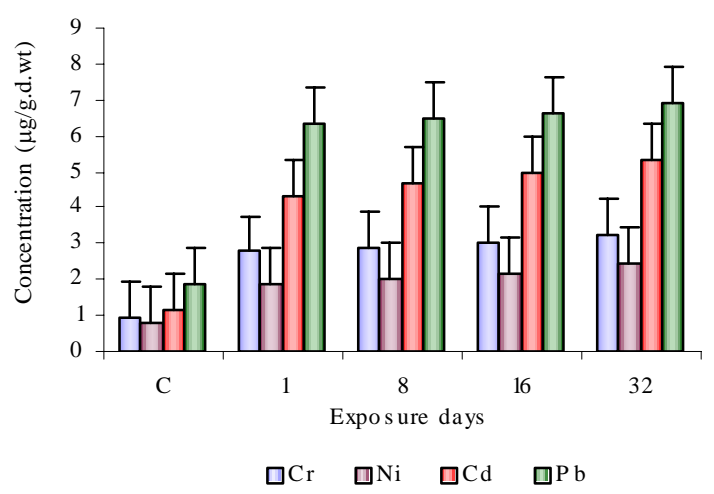

Fig. 3: Accumulation of heavy metals in kidney

The information can be used to evaluate the biochemical changes in the fish metabolism. In this study, the order of heavy metal accumulation in the gills and liver was $\mathrm{Cd}>\mathrm{Pb}>\mathrm{Ni}>\mathrm{Cr}$ and $\mathrm{Pb}>\mathrm{Cd}>\mathrm{Ni}>$ Cr. Similarly, in case of kidney and flesh tissues, the order was $\mathrm{Pb}>\mathrm{Cd}>\mathrm{Cr}>\mathrm{Ni}$ and $\mathrm{Pb}>\mathrm{Cr}>\mathrm{Cd}>\mathrm{Ni}$. In all heavy metals, the bioaccumulation of lead and cadmium proportion was significantly increased in the tissues of Cyprinus carpio (Common carp). Nickel and chromium produce a combined effect in altering the metabolic functions of the fresh water fish. The result indicates that the heavy metal contamination definitely affects the aquatic life of the fresh water fish. Hence, a scientific method detoxification is essential to improve the health of these economic fish in any stressed environmental conditions. Further research studies on the variations in antioxidant enzyme system, due to the influence of heavy metal toxicity in the affected fish, have to be evaluated.

\section{ACKNOWLEDGEMENT}

The authors wish to thank College principal Rev. Dr.

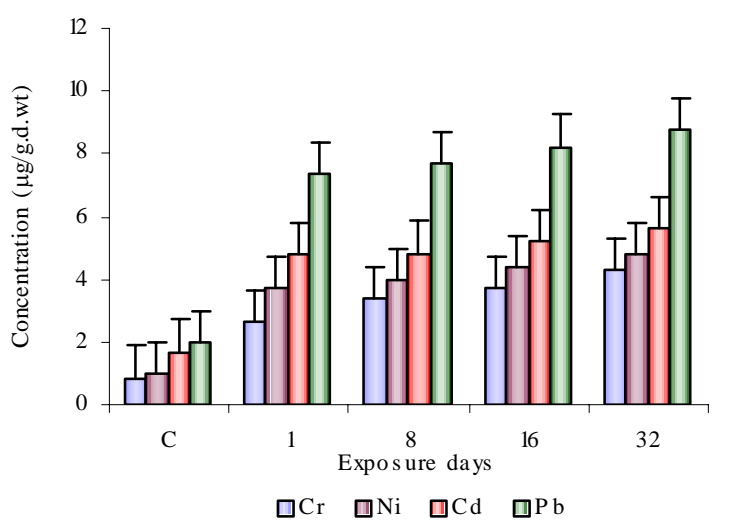

Fig. 2: Accumulation of heavy metals in liver

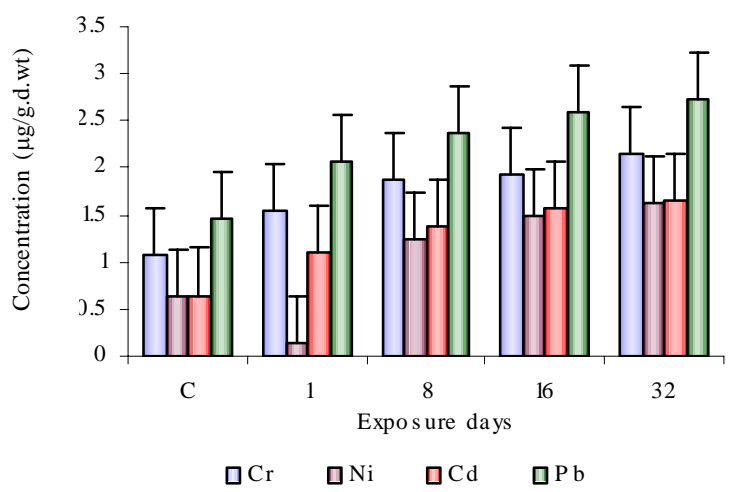

Fig. 4: Accumulation of heavy metals in flesh

Alphonse Manickam and Prof. Thomas Punithan, Head of the Department of Advanced Zoology and Biotechnology, St. Xavier's College (Autonomous), Palayamkottai, Tamilnadu, India, for their kind encouragement and their laboratory facilities.

\section{REFERENCES}

Abou EL-Naga, E. H.; EL-Moselhy, K. M.; Hamed, M. A., (2005). Toxicity of cadmium and copper and their effect on some biochemical parameters of marine fish Mugil seheli. Egyptian. J. Aquat. Res., 31 (2), 60-71.

Adami, G. M.; Barbieri, P.; Fabiani, M.; Piselli, S.; Predonzani, S.; Reisenhofer, E., (2002). Levels of cadmium and zinc in hepatopancreas of reared Mytilus galloprovincialis from the Gulf of Trieste (Italy). Chemosphere, 48 (7), 671 - 677.

Ashraj, W., (2005). Accumulation of heavy metals in kidney and heart tissues of Epinephelus microdon fish from the Arabian Gulf. Environ. Monit. Assess., 101 (1-3), 311-316.

Aucoin, J.; Blanchand, R.; Billiot, C., (1999). Trace metals in fish and sediments from lake Boeuf, South Eastern Louisiana. Micro. Chem. J., 62 (2), 299-307.

Basa, Siraj, P.; Usha Rani, A., (2003). Cadmium induced antioxidant defense mechanism in freshwater teleost Oreochromis mossambicus (Tilapia). Eco. Toxicol. Environ. Saf., 56 (2), $218-221$. 
Bols, N. C.; Brubacher, J. L.; Ganassin, R. C.; Lee, L. E. J., (2001). Ecotoxicology and innate immunity in fish. Dev. с от р. г m m и пол., 25 (8), 853-873.

Canli, M., (1995). Natural occurrence of metallothionein like proteins in the hepatopancreas of the Norway lobster Nephrops Norvegicus and effects of $\mathrm{Cd}, \mathrm{Cu}$, and $\mathrm{Zn}$ exposures on levels of the metal bound on metallothionein. Turk. J. Zool., 19, 313-321.

Canli, M.; Ay, O.; Kalay, M., (1998). Levels of heavy metals $(\mathrm{Cd}, \mathrm{Pb}, \mathrm{Cu}$, and $\mathrm{Ni}$ ) in tissue of Cyprinus Carpio, Barbus Capito and Chondrostoma regium from the Seyhan river. Turk. J. Zool., 22 (3), 149-157.

Clarkson, T. W., (1998). Human toxicology of mercury. J. Trace. Elem. Exp. Med., 11 (2-3), 303-317.

Conacher, H. B.; Page, B. D.; Ryan, J. J., (1993). Industrial chemical contamination of foods [Review]. Food Addit. Contam., 10 (1), 129-143.

Dickman, M. D.; Leung, K. M., (1998). Mercury and organo chlorine exposure from fish consumption in Hong Kong. Chemosphere, 37 (5), 991-1015.

Dirilgen, N., (2001). Accumulation of heavy metals in freshwater organisms: Assessment of toxic interactions. Turk. J. Chem., 25 (3), 173-179.

Dybem, B., (1983). Field sampling and preparation subsamples of aquatic organism for analysis metals and organochlorides. FAO. Fisher. Tech., 212, 1-13.

Farkas, A., Salanki, J.; Specziar, A., (2002). Relation between growth and the heavy metal concentration in organs of bream Abramis brama L. populating lake Balaton. Arch. Environ. Contam. Toxicol., 43 (2), 236-243.

Farombi, E. O.; Adelowo, O. A.; Ajimoko. Y. R., (2007). Biomarkers of oxidative stress and heavy metal levels as indicators of environmental pollution in African Cat fish (Clarias gariepinus) from Nigeria ogun river. Int. J. Environ. Res. Public Health., 4 (2), 158-165.

Ferguson, H. W., (1989). Systematic pathology of fish. Ames. IA: Iowa State University, Press.

Filipovic, V.; Raspor, B., (2003). Metallothionein and metal levels in cytosol of liver, kidney and brain in relation to growth parameters of Mullus surmuletus and Liza aurata. From the eastern Adriatic Sea. Water Res., 37 (13), 32533262 .
Lock, R. A.; Van Overbeeke, A. P., (1981). Effects of mercuric chloride on mucus secretion in rainbow trout, Salmo gairdneri, Richardson. Comp. Biochem. Phys., 69 (1), 67-73.

Mayers, T. R.; Hendricks, J. D., (1984). Histopathology. In GM Rand, S.R. Petrocelli, Eds. Fundamental of aquatic toxicology, Washington DC. Hemisphere.

Olaifa, F. G.; Olaifa, A. K.; Onwude, T. E., (2004). Lethal and sublethal effects of copper to the African Cat fish (Clarias gariepnus). Afr. J. Biomed. Res., 7, 65-70.

Rasmussen, A. D.; Anderson, O., (2000). Effects on cadmium exposure on volume regulation in the lugworm, Arenicola marina. Aquat. Toxicol., 48, 151-164.

Ritterhoff, J.; Zauke, G. P., (1997). Trace metals in field samples of zooplankton from the fram strait and the green sea. Sci. Total. Environ., 199, 255-270.

Tort, L.; Torres, P., (1988). The effects of sub lethal concentration of cadmium on hematological parameters in the dog fish, Scyliorhinus Caniccula. J. Fish. Biol., 32 (2), 277-282.

Usha Rani, A., (2000). Cadmium induced bioaccumulation in tissue of freshwater teleost Oreochromis mossambicus. Ann. N.Y. Acad., 919 (1), 318-320.

Velez, D.; Montoro, R., (1998). Arsenic speciation in manufactured seafood products: a review. J. food. Protect., 61 (9), 1240-1245.

Voegborlo, R. B.; Methnani, A. M. E.; Abedin, M. Z., (1999). Mercury, cadmium and lead content of canned Tuna fish. Food Chem., 67 (4), 341 - 345.

Vosyliene, M. Z.; Jankaite, A., (2006). Effect of heavy metal model mixture on rainbow trout biological parameters. Ekologija., 4, 12-17.

Vutukuru. S. S., (2005). Acute effects of Hexavalent chromium on survival, oxygen consumption, hematological parameters and some biochemical profiles of the Indian Major carp, Labeo rohita. Int. J. Environ. Res. Public Health., 2 (3), 456- 462.

Waqar, A., (2006). Levels of selected heavy metals in Tuna fish. Arab. J. Sci. Eng., 31 (1A), 89-92.

Yousuf, M. H. A.; El-Shahawi., (1999). Trace metals in Lethrinus lentjan fish from Arabian Gulf: Metal accumulation in Kidney and Heart Tissues. Bull. Environ. Contam. Toxicol., 62 (3), 293-300.

\section{AUTHOR (S) BIOSKETCHES}

Vinodhini, R., M.Sc., M.Phil., Ph.D. research student, Aquatic Biodiversity Center, Department of Advanced Zoology and Biotechnology, St.Xavier's College (Autonomous), Palayamkottai - 627 002. Tamilnadu, India. Email: swethasivani@yahoo.co.in

Narayanan, M., M.Sc., Ph.D., Reader in zoology and Director of Aquatic Biodiversity Center, Department of Advanced Zoology and Biotechnology, St.Xavier’s College, Palayamkottai - 627 002. Tamilnadu, India. Email: tvl_narayanm@sancharnet.in

This article should be referenced as follows:

Vinodhini, R.; Narayanan, M., (2008). Bioaccumulation of heavy metals in organs of fresh water fish Cyprinus carpio (Common carp). Int. J. Environ. Sci. Tech., 5 (2), 179-182. 